\title{
Biological Evaluation of Some Plant Bioactives as Feed Additives to Replace Antibiotic Growth Promoters in Broiler Feeds
}

\author{
Sinurat $\mathrm{AP}^{1}$, Pasaribu $\mathrm{T}^{1}$, Purwadaria $\mathrm{T}^{2}$, Haryati $\mathrm{T}^{1}$, Wina $\mathrm{E}^{1}$, Wardhani $\mathrm{T}^{1}$ \\ ${ }^{1}$ Indonesian Research Institute for Animal Production, PO Box 221, Bogor 16002, Indonesia \\ ${ }^{2}$ Faculty of Biotechnology, Atma Jaya Catholic University of Indonesia, Jakarta 12930, Indonesia \\ E-mail: arnoldsinurat@pertanian.go.id
}

(received 29-04-2020; revised 18-05-2020; accepted 18-05-2020)

\begin{abstract}
ABSTRAK
Sinurat AP, Pasaribu T, Purwadaria T, Haryati T, Wina E, Wardhani T. 2020. Evaluasi biologis zat bioktif beberapa tanaman sebagai imbuhan pakan pengganti antibiotik pada ayam broiler. JITV 25(2):81-90. DOI: http://dx.doi.org/10.14334/jitv.v25i2.2501

Antibiotik (AGP) sudah lama digunakan sebagai imbuhan pakan untuk meningkatkan pertumbuhan dan efisiensi penggunaan pakan dalam industri perunggasan. Namun, banyak negara, termasuk Indonesia sudah melarang penggunaannya dan banyak upaya dilakukan untuk mengganti antibiotik agar produktifitas broiler tetap tinggi. Bioaktif tanaman adalah salah satu alternatif yang mungkin dapat menggantikan AGP. Suatu penelitian dilakukan untuk mengganti AGP dengan campuran beberapa sumber zat aktif tanaman yaitu asap cair cangkang mete, tanaman meniran dan daun cengkeh. Delapan (8) ransum perlakuan disusun dengan kandungan gizi yang sama, terdiri dari kontrol negatif (NC), kontrol positif (NC+AGP), ransum NC yang ditambahkan bioaktif tanaman bentuk cair dalam 3 dosis dan ransum NC yang ditambahkan bioaktif tanaman bentuk tepung dalam 3 dosis. Setiap ransum diberikan pada ayam broiler mulai umur sehari hingga 35 hari dengan 6 ulangan tiap perlakuan dan 10 ekor/ulangan. Performan dan indikator respon immunitas ayam diamati selama penelitian. Hasil menunjukkan bahwa penambahan bioaktif tanaman bentuk tepung tidak dapat meningkatkan performan ayam. Penambahan bioaktif tanaman maupun AGP tidak mempengaruhi imunitas ayam broiler. Namun, bioatif tanaman dalam bentuk cair dengan dosis rendah dapat meningkatkan performan ayam broiler, bahkan lebih baik dari peningkatan dengan penambahan antibiotik. Oleh karena itu, kombinasi bioaktif tanaman dalam bentuk cair dengan dosis rendah dapat digunakan sebagai pengganti antibiotik imbuhan pakan (AGP).
\end{abstract}

Kata Kunci: Antibiotic Growth Promoters, Bioaktif Tanaman, Broiler

\begin{abstract}
Sinurat AP, Pasaribu T, Purwadaria T, Haryati T, Wina E, Wardhani T. 2020. Biological evaluation of some plant bioactives as feed additives to replace antibiotic growth promoters in broiler feeds JITV 25(2):81-90. DOI: http://dx.doi.org/10.14334/jitv.v25i2.2501

Antibiotics (AGP) have been used as feed additives to promote growth and feed efficiency in poultry production. However, many countries include Indonesia now ban the use of AGP and attempts are made to replace the antibiotic to maintain good performances of broilers. Plant bioactives is one of the alternatives that could replace the AGP. An experiment was conducted in an attempt to replace the AGP in broiler feed with a mixture of some plant bioactives (liquid smoke of cashew nutshell, Phyllanthus niruri, and clove leaves). Eight (8) dietary treatments were formulated to have similar nutrients consist of negative control (NC), positive control (NC+AGP), diets supplemented with liquid plant bioactives in 3 levels and diets supplemented with powder plant bioactives in 3 levels. Each diet was fed to 6 replications of 10 birds each from 1 to 35 days old. The performances and the immune response of the broilers due to the treatments were observed. Results showed that the powder plant bioactives could not improve the performance of broilers. None of the feed additives (AGP or plant bioactives) affect the immune systems of the broilers. However, liquid plant bioactives in low dose improved the performance of broilers better than the AGP and therefore is suitable to replace the antibiotic as feed additives in broiler diet.
\end{abstract}

Key Words: Antibiotic Growth Promoters, Broilers, Plant Bioactives

\section{INTRODUCTION}

Since the 1940's some antibiotics, known as antibiotic growth promoters (AGP) have been commonly supplemented into poultry feed to improve performances of chickens. The improvement is shown in the mortality reduction, and enhancement in productivity and feed utilization (Dibner \& Richards 2005). Questions about the advantages and disadvantages of using AGP began after Swan Report was submitted by the UK scientific commitee to the parliament in 1969. The report highlighted that "the 
administration of antibiotics to farm livestock possess certain hazards to human and animal health since it has led to the emergence of strains of bacteria which are resistant to antibiotics". Since then, many countries have banned or restricted the use of AGP. Indonesia has started to ban the use of AGP as stated in the Act since 2009 (RI 2009), although the regulation was effectively applied since January 2018.

Some ingredients or materials have been investigated and used in the livestock industry to replace the AGP commercially, such as enzymes, organic acids, plant bioactives, probiotic, prebiotic and synbiotic (Sinurat et al. 2017). Most of these products are imported and more expensive when compared to commercial AGP. Supplementation of exogenous enzymes improves the condition of gastrointestinal (GI) tracts and reduces the microbial population in intestinal such as $C$. perfringens (Sun et al. 2015) and Campylobacter (Wealleans et al. 2017). Supplementation of organic acids into feed lower the $\mathrm{pH}$ in the GI of animals, penetrate the cell wall of bacteria and disrupt their growth and therefore can be used as an alternative to AGP (Hassan et al. 2010; Khodambashi et al. 2013; Khan \& Iqbal 2016; Cengiz et al. 2012). Other substances such as probiotics and prebiotics have been shown to decrease the population of $E$. coli, but increase the population of bifidobacteria and lactobacilli and improved broiler performances similar to the AGP (Afrouziyeh et al. 2014; Mazhari et al. 2016).

Some plants contain active substances or Phyto bioactives that can be used to replace AGP in animal feed. The bioactives are defined as secondary plant metabolites eliciting pharmacological or toxicological effects in man and animals (Blomhoff 2010). Sarica et al. (2007) reported that herbal powder (thyme and garlic) was as effective as AGP (flavomycin) in improving the growth performance of broilers and reducing the population of total aerobic bacteria and $E$. coli in the small intestine. Some studies also showed that the combination of plant bioactives with enzymes (Sarica et al. 2007) or with probiotics, and organic acids (Manafi et al. 2016) showed as good or even better than the AGP in improving performance and immunity of broilers against some diseases. Plant bioactives obtained from Aloe vera leaves have been reported effectively to inhibit the growth of some microbes such as Salmonella hadar and E. coli (Sinurat 2013) and improved the feed conversion efficiency when supplemented in the broiler or laying hens diet (Bintang et al. 2005; Sinurat et al. 2004; Sinurat 2013). Sharifi et al. (2013) also tested four (4) medicinal plants: cumin (Cuminum cyminum), peppermint (Mentha piperita), yarrow (Achillea millefolium) and poley (Teucrium polium) and found the only peppermint could be used as a feed additive to replace the AGP (flavomycin).
As a tropical country, Indonesia is rich in plants that contain bioactives. Some plants have been used traditionally for human healthy food, drinks, and medicines in Indonesia (Affandi et al. 2004). Many studies conducted on plant bioactives aimed to replace the AGP in poultry feed. Most of the studies were based on the active substances found in the extract of one or single plant to inhibit the growth of pathogenic microorganisms or bacteria (Sarica et al. 2007; Oleforuh-Okoleh et al. 2014; Ameri et al. 2016; Sarker et al. 2016; Pasaribu \& Wina 2017; Yesuf et al. 2018; Mashayekhi et al. 2018) although some studies used a combination of some plant bioactives (Ertas et al., 2005, Zaki et al., 2016). A new approach was initiated to find feed additives by combining 3 plant bioactives with high activity as anti-bacteria, anti-fungi, and antioxidant. Sinurat et al. (2018) evaluated 12 plants and found 3 plant bioactives that are potentially used to replace the AGP, i.e., liquid smoke of cashew nuts (Anacardium occidetale) shells (CNSL) effective to inhibit the growth of pathogenic bacteria, clove (Syzygium aromaticum) leaves extract effective to inhibit the growth of fungi and leaf flower (Phyllanthus niruri) extract effective as an antioxidant. Combinations of the three bioactives have been tested in vitro with similar results to AGP in inhibiting the growth of $E$. coli and Salmonella spp. (Pasaribu et al. 2018). Based on those studies, an experiment was designed to study the effectiveness of these bioactives mixture on the performances of broilers.

\section{MATERIALS AND METHODS}

Three plant bioactives, i.e., liquid smoke of cashew nut (Anacardium occidentale) shell (CNSLL), an extract of leaf fruits (Phyllanthus niruri) plants (LF) and extract of clove (Syzygium aromaticum) leaves (CL) were used in this study. Those bioactive were reported to have the highest activity as anti-bacteria, antioxidant, and anti-fungi as reported previously in an in vitro study (Sinurat et al. 2018). A further in vitro study showed that the effective combination of the three bioactives to inhibit the growth of $E$. coli and Salmonella spp. was at the concentration of $0.0313 \%$ CNSL, $0.0313 \%$ LF extracts and $0.0157 \%$ LF extract. Therefore, this combination was used as a basis in this feeding trial. The combined feed additives were formulated in 2 forms, i.e. in liquid or extract form (LPB) and powder form (PPB). The LPB composed of 8.9\% LF extract, $88.8 \% \mathrm{CNSL}$, and $2.3 \% \mathrm{CL}$ extract and the PPB were formulated to contain similar bioactives contents, i.e., $26.7 \%$ LF powder, $66.6 \%$ CNSL and $6.7 \%$ CL powder (Pasaribu et al. 2018). Since the CNSL was already in liquid form, therefore the volume or weight of LF and CL were adjusted to meet the concentration of the combined feed additives. 
Tabel 1. Composition of negative control-starter and grower diet

\begin{tabular}{|c|c|c|}
\hline Ingredients (\%) & Starter & Grower \\
\hline Maize & 60.73 & 62.00 \\
\hline Meat and bone meal & 6.00 & 4.00 \\
\hline Soybean meal & 30.27 & 29.50 \\
\hline Vegetable oil & 1.14 & 2.19 \\
\hline Limestone & 0.18 & 0.77 \\
\hline DL-Methionine & 0.41 & 0.24 \\
\hline Threonine & 0.08 & 0.01 \\
\hline L-Lysine & 0.35 & 0.12 \\
\hline Sodium bicarbonate & 0.10 & 0.10 \\
\hline Salt & 0.20 & 0.20 \\
\hline Vitamin Premixes & 0.03 & 0.03 \\
\hline Mineral Premixes & 0.05 & 0.05 \\
\hline Dicalcium phosphate & 0.36 & 0.69 \\
\hline Choline Chloride & 0.10 & 0.10 \\
\hline Total, \% & 100.00 & 100.00 \\
\hline \multicolumn{3}{|l|}{ Nutrient Content (calculated): } \\
\hline Dry matter, $\%$ & 87.60 & 88.90 \\
\hline Crude fibre, $\%$ & 3.30 & 3.27 \\
\hline Metabolisable energy, $\mathrm{kcal} / \mathrm{g}$ & 2900.00 & 3000.00 \\
\hline Crude Protein, \% & 22.50 & 21.00 \\
\hline Crude fat, $\%$ & 4.69 & 5.56 \\
\hline Calcium, $\%$ & 0.90 & 1.00 \\
\hline Available Phosphorous, \% & 0.50 & 0.45 \\
\hline Digestible Lysine, $\%$ & 1.270 & 1.010 \\
\hline Digestible Methionine, $\%$ & 0.679 & 0.492 \\
\hline Digestible Methionine + Cystine, $\%$ & 0.940 & 0.76 \\
\hline Digestible Tryptophan, $\%$ & 0.219 & 0.213 \\
\hline Digestible Threonine, $\%$ & 0.800 & 0.680 \\
\hline
\end{tabular}

Two control diets, i.e., a negative control- without AGP (NC) and positive control (PC), i.e., the $\mathrm{NC}+40$ ppb zinc bacitracin were formulated. Experimental diets were formulated as a starter diet fed from day old to 21 $\mathrm{d}$ and grower diet fed from 22 to 35 days old broiler chickens. The composition of the control diet is shown in Table 1. The effect of plant bioactives was studied by supplementing the LPB or PPB into the NC diet in three doses, respectively. The levels of supplementation tested were: low LPB (1810 ml/ton diet), medium LPB (3620 $\mathrm{ml} /$ ton diet), high LPB $(5430 \mathrm{ml} /$ ton diet), low PPB (2350 g/ton diet), medium PPB (4700 g/ton diet) and high PPB (7050 g/ton diet). Similar levels were added into the starter ( 0 to 21 days) and grower ( 22 to 35 days) diets. Therefore, 8 dietary treatments were tested in this trial, i.e.:

a. Negative Control diet without AGP (NC)

b. Positive Control diet, i.e, $\mathrm{NC}+40 \mathrm{~g}$ zinc bacitracin $500 \mathrm{~g} /$ ton diet (PC).

c. Low level liquid plant bioactives: $\mathrm{NC}+1810 \mathrm{ml} / \mathrm{ton}$ diet (Low LPB)

d. Medium dose liquid plant bioactives: $\mathrm{NC}+3620$ $\mathrm{ml} /$ ton diet (Medium LPB). 
e. High level liquid plant bioactives, i.e., $\mathrm{NC}+5430$ $\mathrm{ml} /$ ton diet (High LPB).

f. Low-level powder plant bioactives, i.e., $\mathrm{NC}+2350$ $\mathrm{g} /$ ton diet (Low PPB).

g. Medium level powder plant bioactives, i.e., $\mathrm{NC}+4700 \mathrm{~g} /$ ton diet (Medium PPB).

h. High-level powder plant bioactives, i.e., $\mathrm{NC}+7050$ $\mathrm{g} /$ ton diet (High PPB).

Each diet was fed to 60 birds (10 birds per pen with 6 replications) reared in a conventional litter broiler house. Rearing management of the birds was conducted to normal standard procedures where the feed and water were given ad libitum. Feed intake, body weight at 1 day, 21 days, 28 days, and 35 days old, were measured and the survival rates were recorded. At 34 days old, blood samples were taken from the wing vein of 1 bird from each pen. The blood samples were sent to the laboratory to measure the lymphocyte, monocyte, and heterophil as an indication of the immunity levels. At the end of the trial, 1 bird from each cage was slaughtered to measure the carcass percentage, weights of abdomen fat, liver, Fabricius bursa, and spleen.

All data obtained were subject to analyses of variance in a completely randomized design. The difference between treatments was determined by Duncan test if the analyses of variances were significant at $\mathrm{P}<0.05$.

\section{RESULTS AND DISCUSION}

The performance of the birds during the starter period (1 to 21 days old) and grower period ( 1 to 28 days old and 1 to 35 days old) are presented in Tables 2 , 3 , and 4 , respectively. Body weight of the birds at the beginning of the trial or 1 day old was very similar which indicates their homogeneity. The body weight at 21 days old was not significantly $(\mathrm{P}>0.05)$ affected by supplementation of AGP nor by the plant bioactives. However, numerically the heaviest birds were found when the feed was supplemented at low concentration of liquid plant bioactives (778 g) and the lighter birds were found when the birds were fed without feed additives or the negative control (679 g). The body weight of birds feed with the AGP was in between (720 g). The growth improvement was $6.0 \%$ and $14.6 \%$ due to AGP and liquid bioactives supplementation, respectively as compared to the negative control.

Body weight of broilers at 28 and 35 days old were also not significantly $(\mathrm{P}>005)$ affected by supplementation of the AGP nor by the plant bioactives. The treatments effect on body weight at 28 and 35 days have a similar trend as in the starter period. The heaviest birds (1199 $\mathrm{g}$ at 28 days and $1751 \mathrm{~g}$ at 35 days) were achieved when fed with a diet supplemented with low dose liquid plant bioactives. However, the degree of improvement due to AGP or liquid plant bioactives was decreasing as the birds were older. The body weight improvement due to AGP supplementation were $6.0 \%, 2.0 \%$ and $1.3 \%$ at 21,28 and 35 days old and body weight improvement due to low dose liquid plant bioactives supplementation were $14.6 \%, 7.9 \%$ and $4.2 \%$ at 21,28 and 35 days, respectively. Therefore, it was consistent that the highest improvement in body weight was achieved in birds fed a diet with low dose liquid plant bioactives, followed by those fed diets with AGP during the starter and grower period.

Body weight improvement in broilers due to AGP supplementation varied according to some reports such as from $2 \%$ to $9 \%$ (Miles et al. 2006), $5.2 \%$ (Costa et al. 2017), $10.1 \%$ (Mashayekhi et al. 2018) and $14.4 \%$ ( Emami et al. 2012). Reports on the use of plant bioactives as feed additives have been reported with different degrees of improvement on the body weight gain of broilers. Ertas et al. (2005) showed $16.3 \%$ body weight gain improvement by the inclusion of $200 \mathrm{ppm}$ mixed essential oils. Mashayekhi et al. (2018) showed $7.3 \%$ BWG improvement by the inclusion of $0.5 \%$ eucalyptus leaf powder. However, supplementation of mixed medicinal plant leaves in the powder form reduced the body weight gain of broilers by $2.9 \%$ (Aroche et al. 2018), which is similar to our findings in this research. The results found in this experiment indicated that the liquid plant bioactives produce a better body weight improvement as compared to the AGP and therefore, could be used as growth promoters to replace the AGP. The non-significant results found in this trial may be due to large variations among the replications.

The feed intake during the starter and grower periods were not significantly $(\mathrm{P}>0.05)$ affected by the supplementation of AGP nor by the plant bioactives. Supplementation of plant bioactives in powder form tends to increase the feed intake of the broilers and the highest feed intake was found in broilers fed on a low dose of powder plant bioactives, i.e., 1206, 1976 and $2954 \mathrm{~g} / \mathrm{bird}$ and the lowest feed intake was found in broilers fed medium dose of liquid plant bioactives, i.e., 1086, 1820 and $2732 \mathrm{~g} /$ bird during 1 to 21,1 to 28 and 1 to 35 days period, respectively.

Plant bioactives were added without adjustment to the nutrient contents of the diet. The AGP (40 ppb) and the liquid plant bioactives $(0.180$ to $0.543 \%)$ were added in small quantities, while the powder plant bioactives were added in larger quantities ( 0.235 to $0.705 \%$ ) due to make equal bioactives concentration in feed. Therefore, broilers fed with powder plant bioactives tried to meet their nutrient requirements by increasing the feed intake. This trend was only observed during the starter period ( 1 to 21 days), although the differences were not statistically significant. The effect on the feed intake during the grower period however was not consistent and could not be explained. Based on the literature, there was no consistent effect of AGP and 
Table 2. Performance of broilers fed diet supplemented with antibiotic growth promoters (AGP) or plant bioactives during stater period ( 1 to 21 daysay)

\begin{tabular}{lccccc}
\hline \hline Treatments & $\begin{array}{c}\text { Body Weight } \\
\text { DOC }(\mathrm{g})\end{array}$ & $\begin{array}{c}\text { Body Weight } \\
21 \mathrm{~d}(\mathrm{~g})\end{array}$ & $\begin{array}{c}\text { Feed intake } \\
(\mathrm{g} / \mathrm{bird})\end{array}$ & FCR* & $\begin{array}{c}\text { Liveability } \\
(\%)\end{array}$ \\
\hline Negative Control (NC) & $53.9 \pm 2.5$ & $679.2 \pm 90.1$ & $1,116 \pm 103$ & $1.630 \mathrm{ab} \pm 0.102$ & $100.0 \pm 0.0$ \\
Positive Control (NC + AGP) & $53.2 \pm 4.0$ & $720.1 \pm 84.4$ & $1,122 \pm 88$ & $1.593 \mathrm{~b} \pm 089$ & $100.0 \pm 0.0$ \\
NC + Low LPB & $52.9 \pm 3.7$ & $777.7 \pm 75.7$ & $1,1401 \pm 81$ & $1.498 \mathrm{~b} \pm 0.87$ & $98.3 \pm 4.1$ \\
NC + Medium LPB & $53.0 \pm 2.8$ & $689.0 \pm 37.1$ & $1,086 \pm 53$ & $1.578 \mathrm{~b} \pm 0.80$ & $100.0 \pm 0.0$ \\
NC + High LPB & $54.2 \pm 2.8$ & $714.0 \pm 103.3$ & $1,103 \pm 127$ & $1.579 \mathrm{~b} \pm 0.091$ & $98.3 \pm 4.1$ \\
NC + Low PPB & $53.5 \pm 3.7$ & $693.1 \pm 114.4$ & $1,206 \pm 132$ & $1.785 \mathrm{a} \pm 0.146$ & $100.0 \pm 0.0$ \\
NC + Medium PPB & $52.2 \pm 3.5$ & $681.4 \pm 84.0$ & $1,169 \pm 111$ & $1.790 \mathrm{a} \pm 0.154$ & $96.7 \pm 5.2$ \\
NC + High PPB & $53.5 \pm 3.4$ & $713.9 \pm 84.6$ & $1,137 \pm 104$ & $1.632 \mathrm{ab} \pm 0.132$ & $98.3 \pm 4.1$ \\
Significance (P) & 0.99 & 0.58 & 0.49 & 0.003 & 0.47 \\
\hline
\end{tabular}

LPB = Liquid plant bioactives; PPB = Powder plant bioactives

*Different superscripts within the same column showed significant differeneces $(\mathrm{P}<0.05)$

Table 3. Performance of broilers fed diet supplemented with plant bioactives during 1 to 28 days

\begin{tabular}{lcccc}
\hline \hline Treatments & BW 28 days $(\mathrm{g})$ & Feed intake $(\mathrm{g} / \mathrm{bird})$ & FCR $1-28$ days & Liveability $(\%)$ \\
\hline Negative Control (NC) & $1,111 \pm 146$ & $1,897 \pm 146$ & $1.759^{\mathrm{abc}} \pm 0.141$ & $95.0 \pm 8.4$ \\
Positive Control (NC + AGP) & $1,133 \pm 175$ & $1,920 \pm 140$ & $1.714^{\mathrm{bc}} \pm 0.112$ & $96.7 \pm 8.2$ \\
NC + Low LPB & $1,199 \pm 71$ & $1,921 \pm 122$ & $1.647^{\mathrm{c}} \pm 0.063$ & $96.7 \pm 8.2$ \\
NC + Medium LPB & $1,069 \pm 81$ & $1,820 \pm 67$ & $1.726^{\mathrm{bc}} \pm 0.152$ & $93.3 \pm 5.2$ \\
NC + High LPB & $1,134 \pm 120$ & $1,897 \pm 150$ & $1.694^{\mathrm{bc}} \pm 0.088$ & $98.3 \pm 4.1$ \\
NC + Low PPB & $1,100 \pm 133$ & $1,976 \pm 168$ & $1.830^{\mathrm{ab}} \pm 0.113$ & $93.3 \pm 5.2$ \\
NC + Medium PPB & $1,033 \pm 108$ & $1,877 \pm 183$ & $1.920^{\mathrm{a}} \pm 0.176$ & $91.7 \pm 9.8$ \\
NC + High PPB & $1,090 \pm 130$ & $1,902 \pm 144$ & $1.808^{\mathrm{abc}} \pm 0.137$ & $91.7 \pm 7.5$ \\
Significance (P) & 0.48 & 0.78 & 0.02 & 0.68 \\
\hline
\end{tabular}

LPB $=$ Liquid plant bioactives; $\mathrm{PPB}=$ Powder plant bioactives

*Different superscript within the same column showed significant different $(\mathrm{P}<0.05)$

Table 4. Performance of broilers fed diet supplemented with plant bioactives during 1 to 35 days

\begin{tabular}{lcccc}
\hline \hline Treatments & BW 35 days $(\mathrm{g})$ & Feed intake $(\mathrm{g} / \mathrm{bird})$ & FCR & $\begin{array}{c}\text { Liveability } \\
(\%)\end{array}$ \\
\hline Negative Control (NC) & $1,681 \pm 151$ & $2,881 \pm 250$ & $1.790^{\mathrm{bc}} \pm 0.095$ & $95.0 \pm 8.4$ \\
Positive Control (NC + AGP) & $1,700 \pm 176$ & $2,849 \pm 277$ & $1.774^{\mathrm{bc}} \pm 0.067$ & $95.0 \pm 8.4$ \\
NC + Low LPB & $1,751 \pm 94$ & $2,943 \pm 182$ & $1.734^{\mathrm{c}} \pm 0.062$ & $96.7 \pm 8.2$ \\
NC + Medium LPB & $1,649 \pm 120$ & $2,732 \pm 127$ & $1.817^{\mathrm{bc}} \pm 0.093$ & $88.3 \pm 11.7$ \\
NC + High LPB & $1,702 \pm 126$ & $2,917 \pm 219$ & $1.745^{\mathrm{c}} \pm 0.052$ & $98.3 \pm 4.1$ \\
NC + Low PPB & $1,671 \pm 140$ & $2,954 \pm 276$ & $1.840^{\mathrm{abc}} \pm 0.061$ & $93.3 \pm 5.2$ \\
NC + Medium PPB & $1,569 \pm 129$ & $2,801 \pm 308$ & $1.945^{\mathrm{a}} \pm 0.145$ & $90.0 \pm 11.0$ \\
NC + High PPB & $1,650 \pm 118$ & $2,800 \pm 298$ & $1.893^{\mathrm{ab}} \pm 0.126$ & $86.7 \pm 8.2$ \\
Significance (P) & 0.48 & 0.71 & 0.04 & 0.21 \\
\hline
\end{tabular}

LPB = Liquid plant bioactives; PPB = Powder plant bioactives

*Different superscript within the same column showed significant different $(\mathrm{P}<0.05)$ 
other feed additives on feed intake of broilers. Ertas et al. (2005), Fascina et al. (2017), and Mashayekhi et al. (2018) showed that no significant effect of AGP supplementation on the feed intake of broilers. However, Emami et al. (2012) showed an increase in feed intake of broilers due to AGP supplementation. Some reports showed that supplementation of plant bioactive or phytogenic did not alter the feed intake in broilers (Fascina et al. 2017), although Aroche et al. (2018) showed a depression in feed intake due to supplementation of mixed medicinal plant leaves powder.

The feed conversion ratio (FCR) of broilers during starter $(\mathrm{P}<0.01)$ and grower $(\mathrm{P}<0.05)$ periods were significantly affected by the supplementation of the feed additives. The liquid plant bioactives improved the FCR by 3.2 to $8.8 \%$ during the starter period ( 1 to 21 days) as compared to the negative control and the most efficient feed conversion was found when the birds were fed at a low dose of liquid plant bioactives. However, supplementation of plant bioactives in powder form did not show any improvement on the FCR. During the starter period, the most efficient birds to convert the feed were those supplemented with low dose liquid plant bioactives $(\mathrm{FCR}=1.498)$ and the less efficient birds were those fed diet supplemented with medium-dose powder plant bioactives (1.790), while the FCR of birds fed the AGP was slightly better than the negative control $(F C R=1.593)$. Supplementation of low dose liquid plant bioactives improved the FCR by $8.8 \%$ while supplementation of the AGP improved the FCR $2.32 \%$ as compared to the negative control. A similar trend on the FCR during the grower period (1 to 28 days and 1 to 35 days) also occurred but the degree of improvement was decreasing as the birds older. The FCR improvement due to low dose liquid plant bioactives was $8.8 \%, 6.8 \%$, and $3.2 \%$ and the improvement due to AGP supplementation was $2.32 \%$, $2.6 \%$, and $0.9 \%$ from 1 to 21 daysays, 1 to 28 and 1 to 35 days period, respectively.

The liquid plant bioactive was more effective than the powder plant bioactive, although were added at the same antibacterial activity measured by in vitro assay (Pasaribu et al. 2018). This might be due to the different specificity of the bioactive compounds in the liquid and powder plant bioactive. In the liquid form, the bioactive compounds were extracted with methanol which might contain more phenolic or antioxidant compounds, and not only the antibacterial compounds. While the bioactive compounds in the powdered form were extracted by fluids that exist in the gastrointestinal tract which is dominated by water and less phenolic compound could be extracted (Altemimi et al. 2017). The liquid form might give a more bioactive effect to broiler performance than that the powder form. The study of other compounds other than antibiotics that influence broiler performance is interesting. It is well known that most medicines are also prepared by extraction which increasing the purity and specificity of bioactive.

The FCR improvement on broilers due to AGP supplementation varied from 3.2\% (Fascina et al. 2017), 4.7\% (Ahmed et al. 2016), 6.7\% (Mashayekhi et al. 2018), and 7.3\% (Ertas et al. 2005). Many efforts on the use of plant bioactives as feed additives to replace the antibiotic have been reported. Different plant bioactives have been investigated with positive or negative results. Ertas et al. (2005) reported a $14.2 \%$ improvement on the FCR of broilers fed with mixed essential oil. Mashayekhi et al. (2018) reported a $4.1 \%$ FCR improvement due to eucalyptus leaf powder. Ahmed et al. (2016) reported that peppermint oil supplementation at $250 \mathrm{mg} / \mathrm{kg}$ diet improved the feed efficiency to a similar improvement by the AGP $(4.7 \%)$ but the supplementation in powder forms did not affect the body weight gain nor the feed efficiency in broilers. Asadi et al. (2017) also reported that supplementation of peppermint powder in broilers diet improved the body weight gain $(14.2 \%)$ and the feed efficiency $(6.4 \%)$. On the other hand, other reports showed that the peppermint essential oils (Emami et al. 2012) or powder (Gurbuz \& Ismael 2016) could not improve body weight and FCR of broilers. Fascina et al. (2017) also showed that a phytogenic additive (mixed of turmeric extract, citrus extract, grape seed extract, cinnamon oil, boldo leaves, and fenugreek seeds) did not improve the FCR in broilers.

This experiment showed that the low dose liquid plant bioactives were the most effective to improve the performance of the broilers. Zhu et al. (2019) also reported an improvement in broiler performance by supplementing low dose commercial plant extract in the diet while increasing the dose to double did not make further improvement. A higher dose of plant bioactive did not improve the performance of the chickens. This might be due to excessive concentration of the active components such as total phenol, tannin, and saponin (Sinurat et al. 2018). Similar results also reported by Attia et al. (2017) which indicated that a high content of bioactive such as tannins in the diet may decrease nutrient digestion and absorption.

The survival rates of the chickens during the starter period were very high, i.e. 96.7-100.0\%, and were not significantly affected by the treatments $(\mathrm{P}>0.05)$. The cumulative survival rates during 1 to $28 \mathrm{~d}$ old and 1 to $35 \mathrm{~d}$ old periods were quite low due to the occurrence of chronic respiratory disease (CRD) at $26 \mathrm{~d}$ old. However, the survival rates were not significantly affected by treatments $(\mathrm{P}>0.05)$.

One of the compounds in plant bioactives tested in this trial was extract or powder of leaf fruit which has a high antioxidant level (Sinurat et al. 2018). Therefore, 
the inclusion of this substance in the feed was expected to increase the immune system in the blood circulation of the chickens. The effect of the treatments on the leucocyte differential counts in the blood is presented in Table 5 and the effect on the immune organs is presented in Table 6. The heterophils and monocyte in the blood of the broilers were not significantly $(\mathrm{P}>0.05)$ affected by supplementation of the AGP, but the lymphocyte (L) was significantly $(\mathrm{P}<0.05)$ affected. The highest percentage of lymphocyte was found in birds fed a diet supplemented with low dose liquid plant bioactives $(75.2 \%)$ and the lowest percentage was found in birds fed a diet supplemented with high dose powder plant bioactives $(67.0 \%)$. These results showed that neither the supplementation of AGP nor the plant bioactives (except the high dose of powder plant bioactives) significantly ( $>0.05)$ affect the phagocyte levels as compared to the negative control. The ratio between heterophils and lymphocyte (H:L ratio) was also not significantly $(\mathrm{P}>0.05)$ affected by the treatments.

The H:L ratio in the blood has been shown as a good indication of stress in chickens. Chickens with the high-stress condition will have a higher $\mathrm{H}$ :L ratio in the blood (Scanes 2016). This was also shown in broilers challenged with coccidiosis (Moraes et al. 2019). Supplementation of AGP or plant bioactives is expected to improve the immunity of the birds, hence decrease the H:L ratio in the blood. Moraes et al. (2019) also showed that the supplementation of feed additives did not alter the $\mathrm{H}: \mathrm{L}$ ratio in unchallenged birds, but alleviate the $\mathrm{H}: \mathrm{L}$ ratio in broilers challenged with coccidiosis. Helal et al. (2015) showed that feeding the AGP did not affect the lymphocyte, heterophils, monocyte, and the H:L ratio in the blood of broilers. Wahjuni (2017) also showed that the extracts of Phyllanthus niruri L. decreased the number of lymphocytes on infected broilers with enterotoxin Escherichia coli's antibiotics resistant. Some reports showed that supplementation of blend plant extract (Attia et al. 2017) or mixed powder of medicinal plants (Aroche et al. 2018) into feed increased the immunity of broilers significantly as measured by the titer antibody levels or by immunoglobulin concentrations in the serum.

The relative weight of some immune organs of broilers due to AGP or plant bioactives supplementation in the diet is presented in Table 6. Results showed that none of the immune organ's weight (liver, spleen, and bursa of facbricius) was significantly $(\mathrm{P}>0.05)$ affected by the feed additives. The relative weight of immune organs such as bursa fabricius, spleen, and thymus were increased by feeding AGP or organic acids in (AbdelFattah et al. 2008; (Mohamed et al. 2014). However, Fascina et al. (2017) showed that supplementation of feed additives such as AGP, phytogenic or organic acids did not affect the weight of the liver, bursa of fabricius, spleen, and thymus of broilers.

Table 5. The Leucocyte differential count in blood of broilers at 34 days old as affected by feeding different additives

\begin{tabular}{lcccc}
\hline \hline \multirow{2}{*}{ Treatments } & \multicolumn{3}{c}{ Leucocyte differential count } \\
\cline { 2 - 5 } & Heterophils (H) & Monocyte & Lymphocyte (L) & H:L \\
& $\%$ & $\%$ & $74.7^{\mathrm{a}}$ & 0.22 \\
\hline Negative Control (NC) & 16.3 & 9.5 & $74.2^{\mathrm{a}}$ & 0.25 \\
Positive Control (NC+ AGP) & 18.7 & 9.2 & $75.2^{\mathrm{a}}$ & 0.24 \\
NC + Low LPB & 17.5 & 9.5 & $74.5^{\mathrm{a}}$ & 0.24 \\
NC + Medium LPB & 17.7 & 7.5 & $71.8^{\mathrm{ab}}$ & 0.25 \\
NC + High LPB & 18.0 & 10.2 & $72.2^{\mathrm{a}}$ & 0.27 \\
NC + Low PPB & 19.7 & 9.8 & $75.2^{\mathrm{a}}$ & 0.23 \\
NC + Medium PPB & 16.7 & 8.2 & $67.0^{\mathrm{b}}$ & 0.29 \\
NC + High PPB & 19.0 & 12.3 & 0.04 & 0.79 \\
Significance (P) & 0.93 & 0.34 & \multicolumn{2}{c}{0.29} \\
\hline
\end{tabular}

LPB = Liquid plant bioactives; PPB = Powder plant bioactives

*Different superscript within the same column showed significant different $(\mathrm{P}<0.05)$ 
Table 6. The relative weight of some immune organs of broilers at $35 \mathrm{~d}$ old fed with antibiotic or plant bioactves as additives

\begin{tabular}{lccc}
\hline \hline Treatments & $\begin{array}{c}\text { Liver } \\
(\% \text { live weight })\end{array}$ & $\begin{array}{c}\text { Spleen } \\
\text { (\% live weight) }\end{array}$ & $\begin{array}{c}\text { Bursa of fabricious } \\
(\% \text { live weight })\end{array}$ \\
\hline Negative Control (NC) & 2.32 & 0.112 & 0.072 \\
Positive Control (NC + AGP) & 1.99 & 0.113 & 0.062 \\
Negative Control (NC) & 2.13 & 0.123 & 0.050 \\
Positive Control (NC + AGP) & 1.97 & 0.125 & 0.073 \\
NC + Low LPB & 2.00 & 0.128 & 0.048 \\
NC + Medium LPB & 2.14 & 0.118 & 0.063 \\
NC + High LPB & 2.03 & 0.140 & 0.075 \\
NC + Low PPB & 2.08 & 0.132 & 0.063 \\
NC + Medium PPB & 0.56 & 0.78 & 0.45 \\
\hline
\end{tabular}

LPB = Liquid plant bioactives; PPB = Powder plant bioactives

Wallace et al. (2010) have listed the use of some plant material and plant extracts as feed additives in poultry nutrition. Some have beneficial on the immunity status and general performance (body weight, feed efficiency), increase muscle proportion, and reduce lipid contents in meat. Some of the plant bioactives did not have any effect on the performance, even some have a detrimental effect on the performances and immune responses of the chickens. Therefore, the effect of plant bioactives used as feed additives in poultry could not be generalized.

Definitive mechanisms on how the plant bioactive improves the performance of chickens could not be concluded from this experiment. To replace the AGP, plant bioactives used in this experiment were formulated to have three functions, i.e., antibacterial (represented by liquid smoke of cashew nutshell), anti fungi (represented by clove leaves) and immunomodulators (represented by leaf fruits) as reported by Sinurat et al. (2018). The mixture of these three materials, especially the liquid or extract form may have worked synergistically as they improved the performance i.e., the feed conversion ratio of the broilers better than the AGP.

The results of this experiment showed that plant bioactives showed different effects on the performance of the broilers when fed in different forms (powder or liquid) and concentrations. This experiment showed that the best performance improvement was achieved when the plant bioactives fed in a low dose which gave higher improvement than the AGP. It is interesting to explore if a lower dose than used in this experiment could perform a similar improvement to minimize the cost of the feed additives.

\section{CONCLUSION}

It is concluded that supplementation of low dose liquid plant bioactive into the diet, improved the performance of broilers, especially the feed conversion efficiency. Supplementation of the plant bioactive in powder form however did not show any effect on the performance of the broilers.

\section{REFERENCES}

Abdel-Fattah SA, El-Sanhoury MH, El-Mednay NM, AbdelAzeem F. 2008. Thyroid activity, some blood constituents, organs morphology and performance of broiler chicks fed supplemental organic acids. Int $\mathbf{J}$ Poult Sci. 7:215-222.

Affandi H, Nuryadin A, Prayogo SB. 2004. Medical herbs of Pasir Mayang, Jambi: ethopharmacy and toxicity screening. Biotropia (Bogor). 22:40-58.

Afrouziyeh M, Hanifian S, Taghinejad M. 2014. Effects of mannan oligosaccharides on ileal digestibility of nutrients and microbial populations in the ceca of broiler chickens. Int J Biosci. 5:373-380.

Ahmed AMH, El-Sanhour MHS, Mostafa MME. 2016. Effect of Peppermint Extracts Inclusion in Broiler Chick Diet on Chick Performance, Plasma Constituents, Carcass Traits and Some Microbial Populations, Enzymatic Activity and Histological Aspects of Small Intestine. Asian J Anim Vet Adv. 11:441-451.

Altemimi A, Lakhssassi N, Baharlouei A, Watson D, Lightfoot D. 2017. Phytochemicals: extraction, isolation, and identification of bioactive compounds from plant extracts. Plants. 6:42. 
Ameri SA, Samadi F, Dastar B, Zeredaran S. 2016. Effect of peppermint (Mentha piperita) powder on immune response of broiler chickens in heat stress. IJAS. 6:435445.

Aroche R, Martínez Y, Ruan Z, Guan G, Waititu S, Nyachoti CM, Más D, Lan S. 2018. Dietary inclusion of a mixed powder of medicinal plant leaves enhances the feed efficiency and immune function in broiler chickens. J Chem. 2018:1-6.

Asadi N, Husseini SD, Tohidian M-T, Abdali N, Mimandipoure A, Rafieian-Kopaei M, Bahmani M. 2017. Performance of broilers supplemented with Peppermint (Mentha piperita L.) powder. J Evid Based Complementary Altern Med. 22:703-706.

Attia G, Hassanein E, Eraky WE-, Gamal ME-, Farahat M, Hernandez- A. 2017. Effect of dietary supplementation with a plant extract blend on the growth performance, lipid profile, immune response and carcass traits of broiler chickens. Int J Poult Sci. 16:248-256.

Bintang I, Sinurat A, Purwadaria P. 2005. Pengaruh tingkat penambahan bioaktif lidah buaya terhadap produksi telur ayam. JITV. 10:85-89.

Blomhoff R. 2010. Role of dietary phytochemicals in oxidative stress. In: Bernhoft A, editor. Bioact Compd plants - benefits risks man Anim. Oslo (Nor): The Norwegian Academy of Science and Letters; p. 52-70.

Cengiz O, Koksal B, Tatli O, Sevim O, Avci H, Epikmen T, Beyaz D, Buyukyoruk S, Boyacioglu M, Uner A, Onol A. 2012. Influence of dietary organic acid blend supplementation and interaction with delayed feed access after hatch on broiler growth performance and intestinal health. Vet Med. 10:515-528.

Costa MC, Bessegatto JA, Alfieri AA, Weese JS, Filho JAB, Oba A. 2017. Different antibiotic growth promoters induce specific changes in the cecal microbiota membership of broiler chicken.Isaacson RE, editor. PLoS One. 12:e0171642.

Dibner JJ, Richards JD. 2005. Antibiotic growth promoters in agriculture: history and mode of action. Poult Sci. 84:634-643.

Ertas ON, Guler T, Ciftci M, Dalkilic B, Simsek UG. 2005. The effect of an essential oil mix derived from Oregano, Clove and Anise on broiler performance. Int J Poult Sci. 4:879-884.

Fascina V, Pasquali G, Carvalho F, Muro E, Vercese F, Aoyagi M, Pezzato A, Gonzales E, Sartori J. 2017. Effects of phytogenic additives and organic Acids, alone or in combination, on the performance, intestinal quality and immune responses of broiler chickens. Rev Bras Ciência Avícola. 19:497-508.

Gurbuz Y, Ismael IA. 2016. Effect of peppermint and basil as feed additive on broiler performance and carcass characteristics. IJAS. 6: 123-126.

Hassan HMA, Mohamed MA, Youssef AW, Hassan ER. 2010. Effect of using organic acids to substitute antibiotic growth promoters on performance and intestinal microflora of broilers. Asian-Australasian J Anim Sci. 23:1348-1353.

Helal M, Youssef F, Moursi M, Khalil W, AbdelDaim M. 2015. Effectiveness of prebiotic as an alternative to the antimicrobial growth promoter on growth performance, blood constituents, intestinal healthiness and immunity of broilers. Alexandria J Vet Sci. 45:13.

Khan SH, Iqbal J. 2016. Recent advances in the role of organic acids in poultry nutrition. J Appl Anim Res. 44:359-369.

Khodambashi Emami N, Samie A, Rahmani HR, Ruiz-Feria CA. 2012. The effect of peppermint essential oil and fructooligosaccharides, as alternatives to virginiamycin, on growth performance, digestibility, gut morphology and immune response of male broilers. Anim Feed Sci Technol. 175:57-64.

Khodambashi Emami N, Zafari Naeini S, Ruiz-Feria CA. 2013. Growth performance, digestibility, immune response and intestinal morphology of male broilers fed phosphorus deficient diets supplemented with microbial phytase and organic acids. Livest Sci. 157:506-513.

Manafi M, Hedayati M, Khalaji S, Kamely M. 2016. Assessment of a natural, non-antibiotic blend on performance, blood biochemistry, intestinal microflora, and morphology of broilers challenged with Escherichia coli. Rev Bras Zootec. 45:745-754.

Mashayekhi H, Mazhari M, Esmaeilipour O. 2018. Eucalyptus leaves powder, antibiotic and probiotic addition to broiler diets: effect on growth performance, immune response, blood components and carcass traits. Animal. 12:2049-2055.

Mazhari M, Esmaeilipor O, Mirmahmoudi R, Badakhshan Y. 2016. Comparison of antibiotic, probiotic and great plantain (Plantago major L.) on growth performance, serum metabolites, immune response and ileal microbial population of broilers. Poult Sci. 4:97-105.

Miles RD, Butcher GD, Henry PR, Littell RC. 2006. Effect of antibiotic growth promoters on broiler performance, intestinal growth parameters, and quantitative morphology. Poult Sci. 85:476-485.

Mohamed MA, Daly EFE-, Azeem NAAE-, Youssef AW, Hassan HMA. 2014. Growth performance and histological changes in ileum and immune related organs of broilers fed organic acids or antibiotic growth promoter. Int J Poult Sci. 13:602-610.

Moraes PO, Andretta I, Cardinal KM, Ceron M, Vilella L, Borille R, Frazzon AP, Frazzon J, Santin E, Ribeiro AML. 2019. Effect of functional oils on the immune response of broilers challenged with Eimeria spp. Animal. 13:2190-2198.

Oleforuh-Okoleh V, Chukwu G, Adeolu A. 2014. Effect of ground ginger and garlic on the growth performance, carcass quality and economics of production of broiler chickens. GJBB. 3:225-229. 
Pasaribu T, Sinurat AP, Wina E, Purwadaria T, Haryati T, Susana IWR. 2018. Effectiveness of bioactive combinations of several plant substances to inhibit the growth of Escherichia coli and Salmonella sp. J Ilmu Ternak dan Vet. 23:112.

Pasaribu T, Wina E. 2017. Komparasi aktivitas tiga jenis asap cair terhadap pertumbuhan mikroba secara in vitro. In Semin Nas Teknol Peternak dan Vet. Bogor (Indones): Pusat Penelitian dan Pengembangan Peternakan; p. 679-685.

[RI] Republik Indonesia. 2009. Undang Undang Republik Indonesia no 18. 2009. Tentang Peternakan dan Kesehatan Hewan. Juncto No. 41 Tahun 2014. Jakarta (Indones): Sekretariat Negara.

Sarica S, Ciftci A, Demir E, Kilinc K, Yildirim Y. 2007. Use of an antibiotic growth promoter and two herbal natural feed additives with and without exogenous enzymes in wheat based broiler diets. S Afr J Anim Sci. 35:61-72.

Sarker M, Kim G-M, Jang D-H, Sharmin F, Yang C-J. 2016. Bamboo vinegar liquid probiotics for replacing antibiotic on the performance and meat quality of broiler chicken. Asian Australas J Biosci Biotechnol. 1:483-491.

Scanes CG. 2016. Biology of stress in poultry with emphasis on glucocorticoids and the heterophil to lymphocyte ratio. Poult Sci. 95:2208-2215.

Sharifi S, Khorsandi S, Khadem A, Salehi A, Moslehi H 2013. The effect of four medicinal plants on the performance, blood biochemical traits and ileal microflora of broiler chicks. Vet Arh. 83:69-80.

Sinurat A. 2013. Bioaktif tanaman lidah buaya sebagai imbuhan pakan unggas. In: Sumarno, Soedjana T, Suradisastra K, editors. Membumikan Iptek Pertan. Jakarta (Indones): IAARD Press.

Sinurat A, Bahri S, Muharsini S, Puastuti W, Priyanti A, Nurhayati I, Priyono. 2017. Kebijakan Pengendalian Penggunaan Antibiotic Growth Promoters dan Ractopamine dalam Mendukung Keamanan Pangan Nasional. Bogor (Indones): Pusat Penelitian dan Pengembangan Peternakan.
Sinurat A, Purwadaria T, Pasaribu T, Rakhmani S, Dharma J, Rosida J, Sitompul S, Udjianto. 2004. Efektifitas bioaktif lidah buaya sebagai imbuhan pakan untuk ayam broiler yang diperoleh di atas litter. JITV. 9:145-150.

Sinurat AP, Wina E, Rakhmani SIW, Wardhani T, Haryati T, Purwadaria T. 2018. Bioactive substances of some herbals and their effectiveness as antioxidant, antibacteria and antifungi. JITV. 23:18.

Sun Q, Liu D, Guo S, Chen Y, Guo Y. 2015. Effects of dietary essential oil and enzyme supplementation on growth performance and gut health of broilers challenged by Clostridium perfringens. Anim Feed Sci Technol. 207:234-244.

Wahjuni RS. 2017. Effectiveness Meniran (Phyllanthus niruri Linn) as immunomodulation on lymphocyte of broiler infected with enterotoxin Escherichia coli resistant antibiotics. J Vokasi Indones. 5:17-20.

Wallace RJ, Oleszek W, Franz C, Hahn I, Baser KHC, Mathe A, Teichmann K. 2010. Dietary plant bioactives for poultry health and productivity. Br Poult Sci. 51:461487.

Wealleans AL, Walsh MC, Romero LF, Ravindran V. 2017. Comparative effects of two multi-enzyme combinations and a Bacillus probiotic on growth performance, digestibility of energy and nutrients, disappearance of non-starch polysaccharides, and gut microflora in broiler chickens. Poult Sci. 96:4287-4297.

Yesuf K, Mersso B, Bekele T. 2018. Effects of different levels of turmeric, fenugreek and black cumin on carcass characteristics of broiler chicken. J Livest Sci. 8:11-17.

Zaki MM, Abd El-Ghany WA, Hady MM, Korany RMS. 2016. Effect of certain phytobiotics on the immune response of Newcastel Disease vaccinated broiler chickens. Asian J Poult Sci. 10: 134-140.

Zhu N, Wang J, Yu L, Zhang Q, Chen K, Liu B. 2019. Modulation of Growth Performance and Intestinal Microbiota in Chickens Fed Plant Extracts or Virginiamycin. Front Microbiol. 10:1-16. 